Brit. J. industr. Med., 1965, 22, 181.

\title{
LEAD EXPOSURE AND THE DERIVATION OF MAXIMUM ALLOWABLE CONCENTRATIONS AND THRESHOLD LIMIT VALUES
}

\author{
BY \\ KENZABURO TSUCHIYA and SUSUMU HARASHIMA \\ From the Department of Preventive Medicine and Public Health, School of Medicine, \\ Keio University, Tokyo, Japan
}

(RECEIVED FOR PUBLICATION JULY 1964)

\begin{abstract}
The terms maximum allowable concentration (M.A.C.) and threshold limit value (T.L.V.) differ in their respective meanings. The M.A.C. is a ceiling concentration whereas the T.L.V. is a time-weighted average of the concentration of the hazardous agent in the atmosphere. The value attributed to M.A.C. or T.L.V. will vary with the criteria decided upon for the response selected. This response may be a clinical or biochemical change in human subjects resulting from the hazardous agent.

An investigation of lead workers is reported, and from the data obtained from them and from their working environment recommendations have been made. The survey was carried out in printing works and storage battery factories; the order of development of abnormal biochemical findings was reconfirmed. The T.L.V. was determined for each stage of lead absorption by a graphic method. T.L.V.s for an eight to 10 -hour working day were determined as $0.10 \mathrm{mg} . / \mathrm{m} .^{3}$ to produce a urinary lead of $0.15 \mathrm{mg} . / 1 ., 0.12 \mathrm{mg} . / \mathrm{m}^{3}$ for a coproporphyrinuria of about $50 \mu \mathrm{g} . / 1$, $0.14 \mathrm{mg} . / \mathrm{m}^{3}$ for basophilic stippling at the 0.3 per thousand level, and most likely 0.14 to $0.15 \mathrm{mg} . / \mathrm{m}^{3}$ for lead anaemia. The biochemical function chosen was an increased excretion of coproporphyrin, and to keep this below $50 \mu \mathrm{g}$./l. we would suggest that the T.L.V. should be about $0.12 \mathrm{mg} . / \mathrm{m} .^{3}$ or a little more in the case of a 40 -hour week.
\end{abstract}

The setting of maximum allowable concentrations (M.A.C.) and of threshold limit values (T.L.V.) has been the subject of much discussion and speculation in the past. It is easy to state broadly the purpose of such standards; namely, to protect the health of workers from injury by toxic substances encountered at their work. However, when one comes to consider the details involved in setting these values, there are many complications. Among these is the question of the level of health protection that is desired and how this level is to be assessed. This is particularly true when insidious, cumulative poisons are under consideration. To say that the risk of any biological change must be totally excluded is unrealistic, at least in the present state of development of industry. Whether it will ever become possible to avoid every recognizable change is open to question; certainly the question 'how safe' is a philosophical one which could be argued at great length and one in which we do not intend to become involved in this communication.
Several methods have been used to determine the M.A.C. and T.L.V. for given types of dust or vapour. They may be field and medical studies, field studies without medical examination, animal experiments and by analogy with similar substances (Elkins, 1959). The method used in the present research is a field and medical study. We have considered various signs of lead absorption in relation to the lead concentration in various workrooms. A method is demonstrated whereby M.A.C. and T.L.V. values can be set to produce the level of protection chosen as appropriate for the particular community.

An attempt is made to show the derivation of the T.L.V. of lead in working environments where workers are exposed for eight to 10 hours daily for six days a week. Before the onset of clinical symptoms and signs there are several indices of lead absorption which may be related to lead in air concentrations. The first evidence of lead absorption is a raised concentration of lead in the blood and in the urine. In this first stage, however, no recognizable 
biological change is detected in the human body. The second stage is a biochemical change in the enzyme system for porphyrins; this might be regarded as one of the earliest biological changes produced by lead (De Langen and Ten Berg, 1948; Maloof, 1950; and Iwai, 1959). Basophilic stippled red cells follow the increased coproporphyrin excretion (De Langen and Ten Berg, 1948) while lead anaemia is likely to appear if the exposure becomes greater. This may be followed by various lead poisoning symptoms including colic and palsy.

Although these stages do not follow the same sequence in every case and very often two or more of them are present simultaneously, the authors were able to identify them when the lead concentrations were relatively low and varied within a relatively small range. We have considered the literature together with our own findings and suggest figures for the M.A.C. and T.L.V. of lead in air based on the biological effects of lead on the human body. We have distinguished the definition of threshold limit value from that of maximum allowable concentration. The Z-37 Committee of the American Standards Association (1960) has defined the M.A.C. as a limiting concentration or ceiling below which all values should fluctuate. The T.L.V. of the American Conference of Governmental Industrial Hygienists (1962) is a limiting concentration which should not be exceeded by the average of the time-weighted concentrations throughout the eight-hour day (Stokinger, 1962). We have first established a ceiling value for lead in air and then calculated the T.L.V.

\section{Methods of Study}

A storage battery plant, where some 300 lead workers were employed, was used for part of this study.* This plant was representative of lead works with high lead concentrations in the air. For comparison, printing works were used; here the lead in the air is expected nowadays to be well below $0.15 \mathrm{mg} . / \mathrm{m}^{3}{ }^{3}$ Since the number of employees in printing works is usually rather small, we brought together as one group several of these employing about 30 to 50 workers each. Only workers in the age group 19 to 50 years and having over one year of exposure were included (Horiuchi and Ida, 1955; Harashima, Kondo, and Tsuchiya, 1956).

The air lead samples were collected by membrane filters placed at breathing level (No. 2, diameter $4 \mathrm{~cm}$.) in glass holders which were devised by one of our colleagues and connected to a vacuum pump of 8 to $10 \mathrm{l}$./min. capacity. Lead was analysed by the dithizone mixed colour method in all the samples,

*The survey of the storage battery plant was carried out in November 1959, and that of the printing mills in February 1960.
131 in number. A total of 303 lead workers was examined, including subjective complaints, clinical examinations, and laboratory tests. The laboratory tests were quantitative estimation of coproporphyrins and lead in urine, and basophilic stippled cell count and measurement of the whole blood specific gravity. Coproporphyrin estimation was carried out by the method described by With and Petersen (1954). Punctate basophilia was estimated using Manson-Schwarz's stain; 10,000 red cells were scrutinized and the number of basophilic red cells expressed 'per 1,000 '. Urinary lead was measured by the dithizone mixed colour method. Instead of counting red cells or estimating the haemoglobin content, the specific gravity of the whole blood was measured. We have found that the latter is more simple and accurate in field investigations and have shown that in lead anaemia the specific gravity of the blood very closely parallels red cell counts and haemoglobin amounts when they are estimated accurately by other methods (Tsuchiya, Nishimura; and Shō, 1958). The urinary coproporphyrins and lead concentration values were adjusted to the specific gravity of 1.024 by multiplying the actual concentrations by $24 / G$, where $G$ represents the last two figures of the specific gravity of the original sample (Elkins, 1959). This may be an overcorrection with the Japanese worker. No samples were rejected because of a low specific gravity.

\section{Results}

Classification of Stages of Lead Absorption in Different Lead Operations.-In Table 1 lead concentrations in air, urinary lead values, specific gravity of the whole blood, and urinary coproporphyrins in five lead operations are compared; the Table also shows the number of air samples and of subjects examined. It will be seen that except in the printing operation, the average concentration of lead in the air exceeds commonly accepted threshold limit values. Even in the printing works, where the lead concentration in the air ranged from 0.03 to $0.36 \mathrm{mg} . / \mathrm{m}^{3}, 14.6 \%$ of the examinees excreted coproporphyrins in concentrations greater than $50 \mu \mathrm{g} . / \mathrm{l}$., which was considered to be the upper normal value $(5 \%$ level of significance) (Horiuchi, Fukumura, Ida, and Yoshida, 1955; Tsuchiya, 1964).

In Fig. 1, the percentage of workers showing changes characteristic of lead absorption for each of the tests used are plotted against the corresponding average lead concentration of the working environment for each operation studied. The lead concentration in air is represented by the average value of all the samples in each of the lead operations. These values showed wide ranges as is seen in Table 1 . 
TABLE 1

ATMOSPHERIC LEAD CONCENTRATIONS AND LABORATORY FINDINGS OF WORKERS IN DIFFERENT LEAD OPERATIONS

\begin{tabular}{|c|c|c|c|c|c|c|c|c|c|c|c|c|c|c|c|c|}
\hline \multirow{2}{*}{ Operation } & \multicolumn{4}{|c|}{$\begin{array}{c}\text { Lead Concentration of Air } \\
\left(\mathrm{mg} . / \mathrm{m}^{3}\right)\end{array}$} & \multicolumn{4}{|c|}{ Urinary Lead (mg./1.) } & \multicolumn{4}{|c|}{ Blood Gravity (1.0-) } & \multicolumn{4}{|c|}{ Coproporphyrinuria } \\
\hline & $\begin{array}{c}\text { Aver- } \\
\text { age }\end{array}$ & $\begin{array}{l}\text { Maxi- } \\
\text { mum }\end{array}$ & $\begin{array}{l}\text { Mini- } \\
\text { mum }\end{array}$ & No. & $\begin{array}{l}\text { Aver- } \\
\text { age }\end{array}$ & $\begin{array}{l}\text { Maxi- } \\
\text { mum }\end{array}$ & $\begin{array}{l}\text { Mini- } \\
\text { mum }\end{array}$ & No. & $\begin{array}{l}\text { Aver- } \\
\text { age }\end{array}$ & $\begin{array}{l}\text { Maxi- } \\
\text { mum }\end{array}$ & $\begin{array}{l}\text { Mini- } \\
\text { mum }\end{array}$ & No. & $\begin{array}{c}\text { More } \\
\text { than } \\
50 \mu g . / \\
1 . \%\end{array}$ & 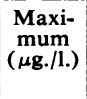 & $\underset{(\mu \mathrm{g} . / 1 .)}{\operatorname{mini}-}$ & No. \\
\hline $\begin{array}{l}\text { Printing } \\
\text { Plate }\end{array}$ & $0 \cdot 14$ & $0 \cdot 36$ & 0.03 & 65 & $0 \cdot 119$ & $0 \cdot 33$ & 0.002 & 143 & $57 \cdot 4$ & $61 \cdot 0$ & $51 \cdot 0$ & 143 & $14 \cdot 6$ & 707 & $6 \cdot 0$ & 143 \\
\hline $\begin{array}{l}\text { casting } \\
\text { Grid }\end{array}$ & $0 \cdot 5$ & 0.62 & $0 \cdot 2$ & 20 & $0 \cdot 152$ & $0 \cdot 35$ & 0.04 & 32 & $56 \cdot 2$ & $60 \cdot 0$ & $50 \cdot 0$ & 32 & $48 \cdot 1$ & 671 & $17 \cdot 0$ & 32 \\
\hline assembly & $1 \cdot 0$ & $2 \cdot 10$ & $0 \cdot 2$ & 18 & $0 \cdot 159$ & $0 \cdot 39$ & 0.04 & 69 & $55 \cdot 1$ & $60 \cdot 0$ & $50 \cdot 0$ & 69 & $80 \cdot 9$ & 1,542 & $6 \cdot 7$ & 69 \\
\hline Oxide mixing & $2 \cdot 0$ & $13 \cdot 0$ & $0 \cdot 25$ & 15 & $0 \cdot 165$ & $0 \cdot 39$ & 0.02 & 31 & $53 \cdot 5$ & $58 \cdot 0$ & $44 \cdot 0$ & 31 & $79 \cdot 3$ & 990 & $15 \cdot 7$ & 31 \\
\hline Plate scraping & $5 \cdot 0$ & $14 \cdot 50$ & $1 \cdot 3$ & 13 & $0 \cdot 162$ & 0.42 & 0.01 & 28 & $54 \cdot 2$ & $58 \cdot 0$ & $44 \cdot 0$ & 28 & 96.3 & 1,532 & $29 \cdot 1$ & 28 \\
\hline
\end{tabular}

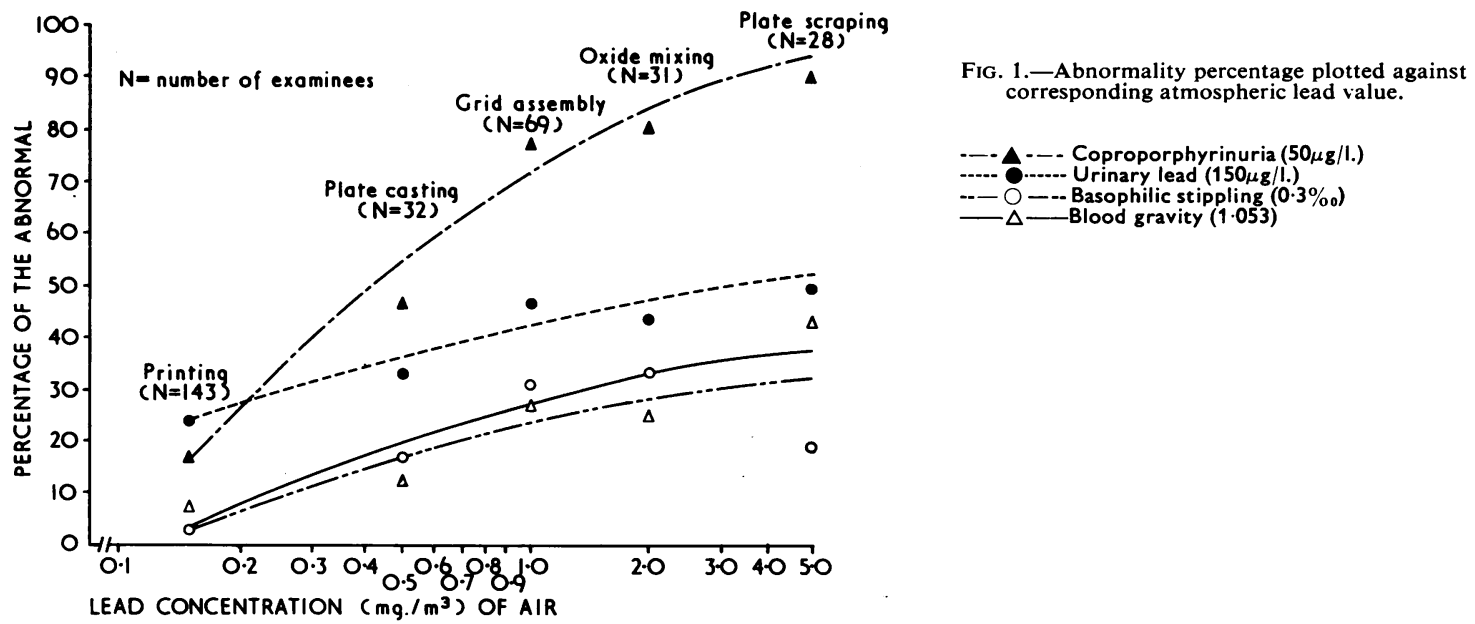

Where lead concentrations in the air are relatively low, as in the printing works, the proportion of workers showing abnormal urinary lead values is higher than the proportion showing coproporphyrinuria. In this operation, those who excreted lead in excess of $0.15 \mathrm{mg} . / \mathrm{l}$. were designated as abnormal, and $23 \%$ were above this value. However, if the normal upper level were set at $0.2 \mathrm{mg}$., the percentage of abnormal becomes approximately $7 \%$ of the examinees in the printing operation. With increasing concentrations of lead in the air, the percentage of those with abnormal coproporphyrinuria gradually rises and surpasses the percentage of those with abnormal urinary lead, and it reaches nearly $100 \%$ in an operation where the atmospheric lead concentration is very high. The percentage showing abnormal urinary lead, basophilic stippling, and anaemia also increased with rising air lead concentrations, but these increases were very gradual and the proportion of the abnormals remained below $50 \%$ even in the most extreme air lead concentrations observed.

Table 2 shows the average values of basophilic stippled cells per 1,000 red cells, classified by copro-

TABLE 2

BASOPHILIC STIPPLING BY COPROPORPHYRINS

\begin{tabular}{l|c|c}
\hline $\begin{array}{c}\text { Coproporphyrin } \\
\text { Concentration } \\
(\mu \mathrm{g} . / 1 .)\end{array}$ & $\begin{array}{c}\text { Basophilic } \\
\text { Stippling } \\
(\%)\end{array}$ & No. \\
\hline $0-50$ & $0 \cdot 23$ & 50 \\
$51-200$ & 0.31 & 37 \\
$201-400$ & 0.32 & 71 \\
$401-$ & 0.62 & 56 \\
\hline
\end{tabular}


porphyrin concentration $(\mu \mathrm{g} . / 1$.$) in the urine. It will$ be seen that the average number of stippled cells increased with the increase of coproporphyrin concentration, and when this exceeded $400 \mu \mathrm{g}$./l. the punctate count rose to 0.62 per 1,000 on the average. With stippling of 0.31 and 0.32 per 1,000 (Cantarow and Trumper, 1944; Johnstone, 1948), which can hardly be called excessive, coproporphyrin concentrations vary from less than 200 to $400 \mu \mathrm{g}$./1., which we regard as clear evidence of increased excretion. From this as well as from Fig. 1, it is shown that increased coproporphyrin excretion precedes the increase of basophilic stippling of red cells.

The relationship between basophilic stippling of red cells and anaemia is summarized in Table 3. The

\section{TABLE 3}

WHOLE BLOOD SPECIFIC GRAVITY (GB) BY BASOPHILIC STIPPLING

\begin{tabular}{|c|c|c|c|c|}
\hline $\begin{array}{c}\text { Basophilic } \\
\text { Stippled Cells } \\
\text { (per 1,000 red cells) }\end{array}$ & $\begin{array}{c}\text { GB } \\
\text { (mean) }\end{array}$ & S.D. & \pm 2 S.E. & No. \\
\hline $\begin{array}{l}0 \\
0 \cdot 1-0 \cdot 4 \\
0 \cdot 5-0 \cdot 9 \\
1-\end{array}$ & $\begin{array}{l}1 \cdot 0 \\
548 \\
544 \\
557 \\
534\end{array}$ & $\begin{array}{l}0 \cdot 00 \\
30 \\
27 \\
22 \\
12\end{array}$ & $\begin{array}{l}542.0<\mathrm{m}<554 \\
538 \\
538<\mathrm{m}<550 \\
547<\mathrm{m}<566 \\
529<\mathrm{m}<539\end{array}$ & $\begin{array}{r}100 \\
94 \\
23 \\
27\end{array}$ \\
\hline
\end{tabular}

increase in the proportion of basophilic stippled red cells parallels the decrease in the specific gravity of blood, except in the range of 0.5 to 0.9 per 1,000 basophilic stippling. In this range, a somewhat irregular increase of the blood gravity is observed. A temporary increase of red cells and haemoglobin due to lead exposure is frequently experienced in human beings and in animal experiments just before the development of anaemia, perhaps indicating stimulation of the bone marrow. When the basophilic stippling becomes more than 1 per 1,000 , lead anaemia becomes definite, with the average blood specific gravity falling to 1.0534 which corresponds to about 3.9 million/c.mm. red cells (Tsuchiya, 1961) and approximately $12.7 \mathrm{~g}$. of haemoglobin (Tsuchiya et al., 1958). It is evident that lead anaemia is generally preceded by an increase of basophilic stippled cells.

Determination of M.A.C. and T.L.V. of Lead in Air.-The data for lead concentration in the air of the printing works, which comprised 55 samples, were plotted on probability paper as shown in Figure 2. The points from $10 \%$ to $90 \%$, which represent cumulative percentages of lead concentrations in the air, mostly fall on a straight line which was mathe-

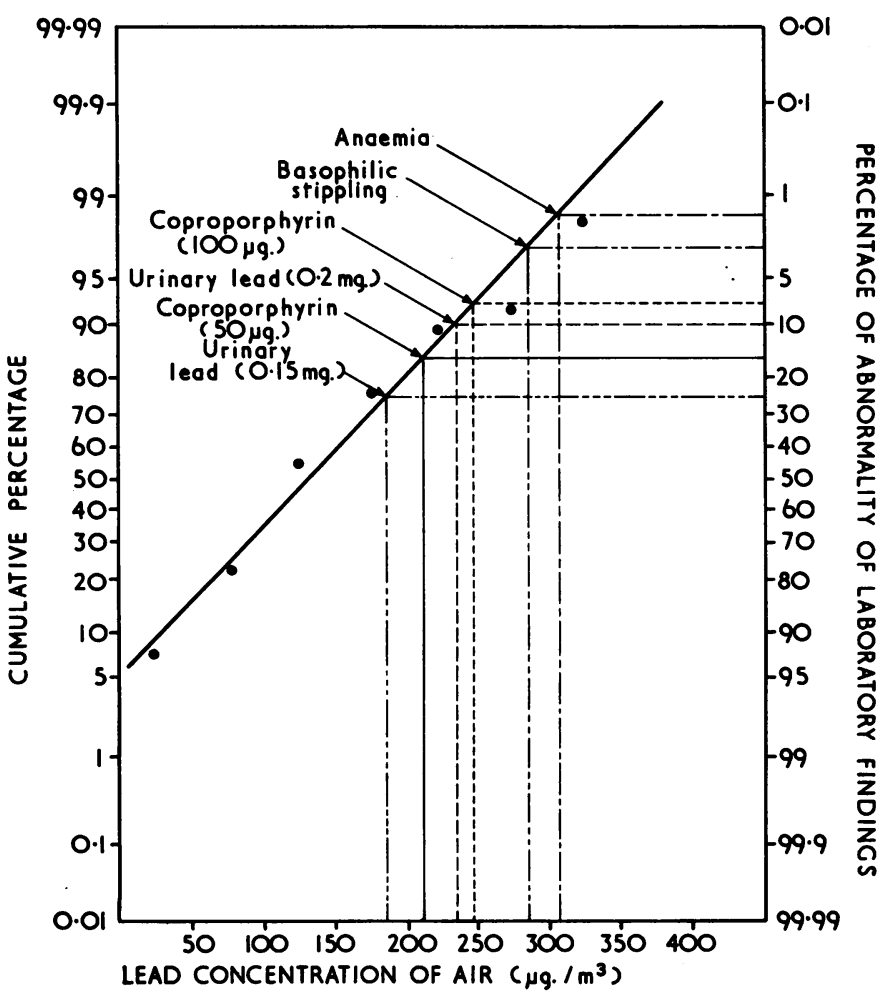

FIG. 2.-Graph to determine M.A.C.s and T.L.V.s. 
matically significant in its linearity. Then we placed an inverse scale for the percentage of workers affected by the various stages of lead absorption at the right of the figure. Thus one can relate the prevalence of any particular state to a particular level of atmospheric contamination, the hypothesis being that the proportion of workers showing a particular stage will be equal to the proportion of air samples showing lead in excess of the ceiling value for that stage. In other words, if $10 \%$ of air samples exceed the ceiling value for lead excretion, then $10 \%$ of workers are expected to show evidence of excessive lead excretion, and if $5 \%$ of the air samples exceed the limit related to basophilic stippling, $5 \%$ of the workers will show this sign of excessive lead absorption.

In our observations, $24 \%$ of the printing plant workers excreted more than $0.15 \mathrm{mg}$. of lead in urine. Now, a line dropped vertically from the point of intersection between the $24 \%$ value on the right scale (or the $76 \%$ value on the left scale) will mark the maximum allowable concentration with respect to urinary lead excretion. This value, which is seen to be $0.18 \mathrm{mg} . / \mathrm{m}^{3}$ according to the hypothesis stated above, should be the ceiling or the maximal allowable concentration in the meaning of the American Standards Association. If this value is never exceeded, the urinary lead of all the workers should remain lower than $0.15 \mathrm{mg}$./l. However, since this is only a sample, the abnormality in urinary lead might go 2 S.D. above $24 \%$ (at the $95 \%$ confidence level). Therefore, $24 \%+2$ S.D., which is $31 \%$, should be taken as the general guide. The value of lead concentration in the air corresponding to $31 \%$ of the most sensitive indicator of excessive lead absorption is approximately $0.16 \mathrm{mg} . / \mathrm{m}^{3}$ of air.

Similarly, $15 \%$ of workers excreted over $50 \mu \mathrm{g} . / 1$. of coproporphyrin and the corresponding value of lead concentration in the air on the abscissa was found to be about $0.21 \mathrm{mg} . / \mathrm{m}^{3}$. When the concentrations were all below this level, no workers in this sample had shown an abnormally increased excretion. Two S.D. above $15 \%$ in this sample is $5.5 \%$, so that $20.5 \%$ should be taken for the determination of the ceiling. The value corresponding to $20.5 \%$ on the abnormality scale is approximately $0.19 \mathrm{mg} . / \mathrm{m}^{3}$ on the abscissa. Looking again at urinary lead, when $0.2 \mathrm{mg}$./1. of lead is taken as the lower limit of abnormality, the ceiling would be $0.20 \mathrm{mg} . / \mathrm{m}^{3}{ }^{3}$ of lead in the air. As to basophilic stippling of red cells, $0.3 \%$ of which was taken as the border line, the ceiling was estimated at $0.27 \mathrm{mg} . / \mathrm{m}^{3}$ of lead in the air. The lowest limit of lead in environmental air to produce lead anaemia was almost the same as that for basophilic stippling, according to this chart. However, as mentioned above in a so-called normal group of industrial workers, about $1 \%$ to $5 \%$ were found to have a blood gravity as low as 1.053 or lower. Therefore, as far as the ceiling for the development of lead anaemia is concerned, the value might be slightly increased and most probably should be about $0.28 \mathrm{mg} . / \mathrm{m}^{3}$. M.A.C. values computed in this way for various signs of lead absorption are shown in Table 4.

\section{TABLE 4}

MAXIMUM ALLOWABLE CONCENTRATIONS AND THRESHOLD LIMIT VALUES FOR THE CONTROL OF LEAD ABSORPTION AT LEVELS INDICATED BY VARIOUS TESTS FOR A WORK-WEEK OF 48 TO 60 HOURS

\begin{tabular}{|c|c|c|}
\hline Test & $\underset{\text { (mg./m. }}{\text { M.A.C. }}$ & $\underset{\left(\mathrm{mg} \cdot / \mathrm{m} .^{3}\right)}{\text { T.L.V. }}$ \\
\hline $\begin{array}{l}\text { Urinary lead excretion }(0.15 \mathrm{mg} . / 1 .) \\
\text { Urinary lead excretion }(0.20 \mathrm{mg} . / 1 .) \\
\text { Urinary coproporphyrin excretion }(50 \mu \mathrm{g} . / 1 .) \\
\text { Urinary coproporphyrin excretion }(100 \mu \mathrm{g} . / 1 .) \\
\text { Basophilic stippling of erythrocytes }(0.3 \% \%) \\
\text { Anaemia (blood specific gravity } 1.053)\end{array}$ & $\begin{array}{l}0 \cdot 16 \\
0 \cdot 20 \\
0 \cdot 19 \\
0 \cdot 22 \\
0 \cdot 27 \\
0 \cdot 28\end{array}$ & $\begin{array}{l}0 \cdot 10 \\
0 \cdot 12 \\
0 \cdot 12 \\
0 \cdot 13 \\
0 \cdot 14 \\
0 \cdot 14\end{array}$ \\
\hline
\end{tabular}

The ceiling mentioned above is defined as follows: it is the concentration which must not be exceeded by even one out of many samples taken in an industrial environment with an eight- to 10-hour working day. The T.L.V. is computed as follows: since the T.L.V. refers to the average concentration in the working environment, all values of the samples lower than the ceiling should be averaged, provided the data show a normal distribution curve. Thus the T.L.V. to keep the urinary lead concentration below $0.15 \mathrm{mg} . / 1$. is found from the average of all air samples showing less than $0.16 \mathrm{mg} . / \mathrm{m}^{3}$. The resultant T.L.V. for urinary lead was calculated at about $0.10 \mathrm{mg} . / \mathrm{m}^{3}$ of lead in the air. Similar computations for other signs of lead absorption led to threshold limit values as shown in Table 4.

In our opinion, an increase of coproporphyrin excretion should be treated as the first indication of a deleterious effect of lead absorption. We realize this is a very high standard and is not accepted by all observers. If this is the index accepted, however, the T.L.V. of lead in air should be $0.12 \mathrm{mg} . / \mathrm{m}^{3}$ of air. In the present study the lead workers were exposed to lead for eight to 10 hours daily, for about 48 to 60 hours in six days. If workers are exposed to lead for only $\mathbf{4 0}$ hours per week, what kind of correction will be required? We should not like to make a simple inversely proportional increase in the T.L.V., because we believe that the problem may be more complicated. We have not attempted to resolve this point.

\section{Discussion}

It is generally accepted that as a result of chronic 
lead exposure the increase in urinary coproporphyrins usually precedes the appearance of basophilic stippled cells in the blood and is certainly seen before lead anaemia. Exceptions are occasionally seen in individual workers in whom the stages of reaction do not always follow so precise a pattern: a lead worker may have basophilic stippling without coproporphyrinuria. In this study, however, individual values are grouped and the average group value has been used. We found coproporphyrinuria in almost $100 \%$ of the workers exposed to a high concentration of lead. In printing works where the lead concentration in the air is about $0.15 \mathrm{mg} . / \mathrm{m}^{3}$ the range of variation was relatively small. The order of frequency of abnormal laboratory findings was urinary lead $0.15 \mathrm{mg}$./l. or more, coproporphyrinuria $50 \mu \mathrm{g}$./1. or more, urinary lead $0.2 \mathrm{mg}$./l. or more, basophilic stippling, and anaemia.

Up to the present time T.L.V.s of lead in the air have been reported from the United States by the American Conference of Governmental Industrial Hygienists (A.C.G.I.H.) (1962) (Elkins, 1959), from Japan (Horiuchi and Ida, 1955), and from Russia (Elkins, 1961). It seems that there has been some confusion in the definition of M.A.C. and T.L.V. (Stokinger, 1955). In this paper we wish to stress the difference between these two definitions and have tried to determine the T.L.V. of lead according to a precise meaning of the term. The A.C.G.I.H. has adopted $0.2 \mathrm{mg} . / \mathrm{m}^{3}$; this was based on a urinary lead level of $0.2 \mathrm{mg} . / \mathrm{l}$. The figure suggested by Horiuchi and Ida (1955) is much lower; they set the T.L.V. at $0.05 \mathrm{mg} . / \mathrm{m}^{3}$.

We appreciate that an increase of coproporphyrin excretion is an extremely sensitive index of lead absorption, and it is not altogether clear whether the individual suffers harm as a result of this biochemical abnormality. Despite this we have regarded an increase of coproporphyrin excretion as undesirable and have based our recommendations accordingly. We suggest that the ceiling for lead in the air is about $0.19 \mathrm{mg} . / \mathrm{m}^{3}$ and the T.L.V. should be about 0.12 $\mathrm{mg} . / \mathrm{m}^{3}$ for a daily exposure of eight to 10 hours. Our figure is about midway between the A.C.G.I.H. value $(0.2 \mathrm{mg}$.) and that of Horiuchi et al. (1955) $(0.05 \mathrm{mg}$.). However, the American value is based on a 40-hour working week which is much shorter than that used in our study. When the length of the working week is taken into consideration the value will be closer to that suggested here.

\section{REFERENCES}

American Conference of Governmental Industrial Hygienists (1962). Documentation of Threshold Limit Values.

American Standards Association (1960). The Meaning of Maximal

Acceptable Concentration. Z 37.
Cantarow, A., and Trumper, M. (1944). Lead Poisoning, pp. 147 and 158. Williams and Wilkins, Baltimore.

De Langen, C. D., and Ten Berg, J. A. G. (1948). Acta med. scand., 130,37 .

Elkins, H. B. (1959). The Chemistry of Industrial Toxicology, 2nd ed., p. 241. John Wiley, New York.

Harashima, S., Kondo, H., Hith , $2,45$. Hlth, 3, 294. (In Japanese.)

Horiuchi, K., Fukumura, S., Ida, N., and Yoshida, Y. (1955). Osaka City med. J., 2, 73. Or 'Contributions' from the Dept. of Prev. Med. and Publ. Hith, Osaka City Univ. Med. School, 1, 80. (1959).

- , and Ida, N. (1955). Osaka City med. J., 2, 57. Or 'Contributions' from the Dept. of Prev. Med. and Publ. Hith, Osaka City Univ. Med. School, 1, 80. (1959).

Iwai, S. (1959). Jap. J. industr. Hlth, 1, 746.' (In Japanese.)

Johnstone, R. T. (1948). Occupational Medicine and Industrial Hygiene. p. 246. Henry Kimpton, London.

Maloof, C. C. (1950). Arch. industr. Hyg., 1, 296.

Stokinger, H. E. (1955). Publ. Hlth Rep. (Wash.), 70, 1.

Tsuchiya, K. (1961). Jap. J. . Hdustr. Hyg., 2, 4. (In Japanese.) (1964). Coproporphyrins in lead and mercury workers. Ind. Health, 2, 162.

Nishimura, M., and Shö, K. (1958). J. Sci. Labour (Tokyo), 34, 1. (In Japanese with English summary.)

With, T. K., and Petersen, H. C. A. (1954). Lancet, 2, 1148. 